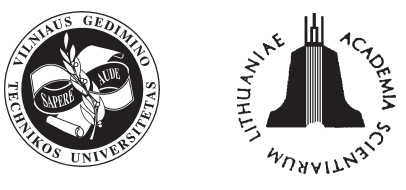

\title{
CONCEPT OF ECONOMICAL-MATHEMATICAL MODEL OF LAND MARKET
}

\author{
Gintautas Šatkauskas \\ Vilnius Gediminas Technical University, Saulètekio al. 11, LT-10223 Vilnius, Lithuania \\ E-mail: Gintautas.Satkauskas@st.vgtu.lt
}

Received 10 Nov 2007; accepted 17 Dec 2007

\begin{abstract}
Input parameters, ie factors defining the market price of agricultural-purpose land, are interrelated very often by means of non-linear ties. Strength of these ties is rather different and this limits usefulness of information in the research process of land market prices. Influence of input parameter changes to the input parameters in case when there are rather substantial changes may be determined in someone direction with a sufficient precision, whereas in other directions with comparatively small changes of input parameters this influence is difficult to be separated from the "noise" background. Taking into account the above-listed circumstances, the concept of economical-mathematical model of land market should be as follows: there is carried out re-parameterisation of the process by means of introduction of new parameters in such a way that the new parameters are not interrelated, and the full process is evaluated at the minimal number of these parameters. These requirements are met by the main components of the input parameters. Then normalisation of the main components is carried out and dependencies on new parameters are determined. It is easier to interpret the dependencies obtained having reduced the number of input parameters and the higher the non-linearity of interrelations of primary land market data, the greater effect of normalisation of input-parameter components. The results are compared with the valuations of experts.
\end{abstract}

Keywords: land market, market and normative valuation of the land, methods of appraisal and mass-appraisal valuation of land, normative price of land, land tax, rent.

\section{Introduction}

Since passing the Land Laws of the Republic of Lithuania, the land market has been legalised and a system of its legal relations has been created. As the basis of agricultural production is the land, the investigations into the transformation of land relations are very important for scientific knowledge of processes going on in agriculture and necessary for the formation of State policy in land relations.

During the period of transition to market economy, most attention in pricing investigations has been paid to macroeconomic indexes: gross national product and its growth, budget revenue and expenditures, interest rate of credit, inflation.

However, under market conditions, it is important to investigate demand and supply - the principal indexes of macroeconomics. Theoretic fundamentals of demand and supply analysis show that changes of demand and supply provoke changes of price, and vice versa - what is the effect of price changes on the mentioned indexes.

In our country, the land market in the process of its formation is attempted to be investigated by the State Land Survey under the Ministry of Agriculture. But investigations, being carried out by this department, cannot give any appreciable results without the application of serious theoretic methods.

Regression is also widely used in investigations of land prices around the world [1-6].

There is no agreement in the literature on the best functional form of the mathematical models. Rosen [7] stressed that economic theory fails to indicate any particular form as being appropriate. The problem is discussed in [8-10]. According to O'Connor [10], though all 3 models (additive, multiplicative, and non-linear) produce excellent results, the multiplicative model obtains the best results, and the hybrid model offers a better representation of appraisal principles. Halvorsen and Pollakowski [11] and Wilhelmsson [12] use a flexible multi-parameter Box-Cox model to find the best-fitting transformation. However, as a linear model describes the relationships more clearly in general and its results are easier to compare with the expert 
valuations, the focus of our attention is on this type of model even though we compare our results with results from the loglinear model. Hence, in our econometric modelling, two types of ordinary least square (OLS) models are specified: linear and log-linear.

The newest scientifical researches in this branch are multiple criteria analysis [13].

\section{Model concept}

Input parameters, ie factors defining the market price of agricultural-purpose land are interrelated very often by means of non-linear ties. Strength of these ties is rather different and this limits usefulness of information in the research process of land market prices. Influence of input parameter changes on the input parameters, when there are rather substantial changes, may be determined in some direction with a sufficient precision, whereas in other directions with comparatively small changes of input parameters this influence is difficult to be separated from the "noise" background [14].

Really, interrelations of input parameters create a lot of computational difficulties: in case of linear dependence among the input parameters and when number of market data is less than that of parameters under investigation (the case characteristic to this market research), the method proposed by the Service of Land at the Ministry of Agriculture is not applicable at all. When the input parameters are interrelated rather strongly, then definiteness of coefficient matrix of the normal equation system is low and this leads to substantial errors of regression equation coefficients. These errors grow when number of input parameters increases [14].

Taking into account the above-listed circumstances, the concept of economical-mathematical model of land market should be as follows: there is carried out reparameterisation of the process by means of introduction of new parameters in such a way that the new parameters are not interrelated, and the full process is evaluated at the minimal number of these parameters. These requirements are met by the main components of the input parameters. Then normalisation of the main components is carried out and dependencies on new parameters are determined. The new input parameters are not interrelated, therefore statistical analysis of regression equations is simplified, solutions are always obtained when solving normal equations, and it is easier to interpret the dependencies obtained having a reduced number of input parameters. Additionally, the higher the non-linearity of interrelations of primary land market data, the greater the effect of normalisation of input-parameter components.

\subsection{Main components of input parameters}

Factors defining the market price of agricultural-purpose land are written as the line of $k$-dimensional vector:

$$
X_{[k x 1]}^{*}=\left(x_{1}, \ldots, x_{k}\right),
$$

where $*$ marks transposition.

We shall mark the market price of agricultural-purpose land as $y$ (output parameter). We shall investigate the $k$-dimensional sample having volume $N$ and defining the output parameter. This sample is described by the matrix $X_{[k x N]}$, ie:

$$
X_{[k x N]}=\left\|x_{i j}\right\|(i=1, \ldots, k ; j=1, \ldots, N),
$$

where the index $i$-factor number, index $j$ - number of the market datum. We shall mark the market prices $y$ (output parameter) of agricultural-purpose land as:

$$
Y_{[1 x N]}=\left(y_{1}, \ldots, y_{N}\right) \text {. }
$$

Estimation of averages of vectors-predictors (input parameters) is the vector:

$$
\bar{X}_{[k x 1]}=\left\|\bar{x}_{i}\right\| \quad(i=1, \ldots, k),
$$

and estimation of the covariant matrix:

$$
\Sigma_{[k x k]}=\frac{1}{N} \stackrel{o}{X}_{[k x N]} \stackrel{o}{X}{ }_{[N x k]}^{*}=\left\|\sigma_{i j}\right\| .
$$

The covariant matrix covering covariances among the input parameters influencing the output parameter is:

$$
Q_{[k x 1]}=\left\|q_{i}\right\| \quad(i=1, \ldots, k) .
$$

Characteristic values of the covariant matrix $\sum_{[k x k]}$ may be obtained from the characteristic equation:

$$
\left|\sum_{[k x k]}-\dot{\mathrm{e}}_{i} J_{[k x k]}\right|=0
$$

where $\lambda_{1}>\lambda_{2}>\ldots>\lambda_{k}$ are roots of the characteristic equation.

Using the equation system:

$$
\left(\sum-\dot{\mathrm{e}}_{i} J\right)_{[k x k]} \cdot A_{[k x 1]}^{(i)}=\mathrm{Q}_{[k x 1]}
$$

where $A_{[k x 1]}^{(i)}=\left(\begin{array}{c}a_{1}^{(i)} \\ a_{2}^{(i)} \\ \cdot \\ \cdot \\ \cdot \\ a_{k}^{(i)}\end{array}\right)$,

we may obtain the values $a_{l}^{(i)}(l=1, \ldots, k)$.

Then the $i$-th characteristic vector is expressed as:

$$
f_{[k x 1]}^{(i)}=\left\|f_{j}^{(i)}\right\|, \quad(j=1, \ldots, k),
$$


where $f_{j}^{(i)}=\frac{a_{j}^{(i)}}{\left(A_{[k x 1]}^{(i)^{*}} A_{[1 x k]}^{(i)}\right)^{0.5}}$,

$$
F_{[k x k]}=\left\|f_{j}^{(i)}\right\|, \quad i=1, \ldots, k, j=1, \ldots, k .
$$

There are: $i$ - number of the characteristic vector, $j-$ coordinate number of the characteristic vector.

The vector

$$
Z_{[1 x k]}^{*}=\left(z_{1}, z_{2}, \ldots, z_{k}\right),
$$

of the main components may be obtained from the dependence:

$$
Z_{[k x 1]}=F_{[k x k]} \cdot X_{[k x 1]} .
$$

Variables $z$ are named as the main components of variables $x$ and have important properties.

\subsection{Normalisation of the main components}

In order to evaluate non-linearity and to increase reliability of parameters of multiple correlation, we carry out normalisation of each transformed variable $z_{i j}$ using empirical probabilities $p_{j}\left(z_{i j}\right) \equiv p_{j i}$ for all values of transformed data $z_{j i}(i=1, \ldots, N)$ according to the dependence:

$$
p_{m}=\frac{m\left(z_{j i}\right)-0.25}{N+0.5}=p_{j}\left(z_{j i}\right)=p_{j i},
$$

where $m\left(z_{j i}\right)=1,2, \ldots, N$ - rank number of input parameters obtained by positioning them in growing order. Corresponding empirical values $u_{j}\left(z_{j i}\right) \equiv u_{j i}=u_{m}$ of already normalised variable $u_{j}\left(z_{j}\right)$ are defined using the normal distribution function:

$$
p_{j}\left(z_{j i}\right)=p_{m}=\frac{1}{\sqrt{2 \pi}} \int_{-\infty}^{u_{m}} e^{-\frac{u^{2}}{2}} d u=\Phi\left(u_{m}\right)
$$

as inverse functions

$$
u_{j i}=\Phi^{-1}\left[p_{j}\left(z_{j i}\right)\right]=u_{j}\left(z_{j i}\right) .
$$

\subsection{Multiple regression of normalised main components}

Transformation of the main components by normalisation enables us to obtain correctly the normalised multiple regression expressed by the dependence:

$$
U_{0}=\alpha_{01} u_{1}+\alpha_{02} u_{2}+\ldots+\alpha_{0 m} u_{m}
$$

of normalised values $u_{0}\left(z_{0}\right)$ as a function of arguments $u_{1}\left(z_{1}\right)$, $u_{2}\left(z_{2}\right), \ldots, u_{m}\left(z_{m}\right)$ by solving the system of $m$ linear equations and determining coefficients $\alpha_{01}, \alpha_{02}, \ldots, \alpha_{0 m}$ of the multiple regression.
The main components enable us to minimise number of factors defining the market price of agricultural-purpose land.

Transformation of the main components by normalisation enables us to evaluate non-linearity and to increase reliability of multiple dependence obtained.

\subsection{Reliability of the function of several variables}

Factors defining the market price of agricultural-purpose land form the system of $k$ random quantities:

$$
\left(x_{1}, x_{2}, \ldots, x_{k}\right) .
$$

As a result of calculation, arithmetic averages of random quantities are obtained

$$
m_{x_{1}}, m_{x_{2}}, \ldots, m_{x_{k}},
$$

correlation matrix $\left\|K_{i j}\right\|$ and dependence:

$$
y=\varphi\left(x_{1}, x_{2}, \ldots, x_{k}\right) .
$$

When investigating errors, it is necessary to define numeric values of the quantity y, i.e. arithmetic average $m_{y}$ and dispersion $D_{y}$. In order to obtain the root-mean-square deviation $D_{y}$ from the dispersion $\sigma_{y}^{2}$, we use the following dependence:

$$
\sigma_{y}^{2}=\sum_{i=1}^{n}\left(\frac{\delta \varphi}{\delta x}\right)_{m}^{2} \sigma_{x_{i}}^{2}+2 \sum_{i<j}\left(\frac{\delta \varphi}{\delta x_{i}}\right)_{m}\left(\frac{\delta \varphi}{\delta x_{j}}\right)_{m} r_{i j} \sigma_{x_{i}} \sigma_{x_{j i}}
$$

where $r_{i j}$ - correlation coefficients of input parameters.

Having transformed input parameters to independent variables $Z_{[k x 1]}=\left(z_{1}, z_{2}, \ldots, z_{k}\right)$, ie $r_{i j}=0$, the above-written formula is modified to the following expression:

$$
\sigma_{y}^{2}=\sum_{i=1}^{n}\left(\frac{\delta \varphi}{\delta x}\right)_{m}^{2} \sigma_{x_{i}}^{2}
$$

When comparing among themselves the components of $\sigma_{x}^{2}$, we define the factor having the greatest error.

\section{Land rent and valuation of agricultural land}

Researches on this category were made in a model and only some of them suited for farming activities. Transition to market economy in all post-communist countries increased the interest in the components of ownership and in the assessment of land as well [15-17]. The value of agricultural land is often estimated by calculating and capitalising the land rent. This paper addresses a new way of calculation of different types of land rent as well as its additive value seeking to set the price of agricultural land.

Types of land rent are: differential rent Ia, Ib, differential rent II, and absolute rent. 


\subsection{Differential rent I}

Main assumption for a land rent is the differential rent. Its origin is decided by the differences in natural conditions for farming. Components of the differential rent are the differences of farming lands measured in grades, duration of vegetation period, amount of rainfall and sun radiation, local terrain, air temperature etc. Traditionally the quality of land is the main indicator. With the improvement of agro-technology this factor is gradually reducing. When natural conditions for farming are estimated in a complex way, the background is the amount of production received from an area unit. Differential rent for a specific parcel is calculated in estimating the influence of natural conditions on agricultural production in kind or expressed in money. Seeking to estimate these values, other factors having influence on farming activities must be considered as stable ones. They include the size of land plots, their location, estimating the possibilities for sale and exploiting, the costs and structures, depending on agro-technical terms and on sale price as well. To estimate the prices of agricultural production the worst land plots are taken but not the best or average ones. The worst land plot has the worst land quality of all land types used for farming. Production received from such land plots is still needed for society, so they must be still in use. The size of farming land plots is fixed and cannot be expanded self-willingly. The use of all agricultural land plots should be taxed.

If the sale prices of agricultural products are estimated on the basis of the costs in the parcels of better quality but not of the worst, the income from the latter (from the worst ones) will be lower than gained from other land plots. In certain cases the income will not cover the costs. Unfortunately, sometimes it happens to us. However, such a situation cannot continue. It is evident if we look at the developed countries, where the agricultural production is one of the forms for capital investments that must generate a minimum profit if compared to other economy branches. A farm to an individual producer of agricultural production is not a direct capital investment. It is his working place. If he is not engaged in other production generating higher income than the agriculture he can miss the possibility for employment. Such a farm will try to survive despite the received income. Nevertheless, poor income from agriculture that is often lower than production costs sooner or later will drive such a farm to decline.

Differential rent Ia can be calculated in two ways. The first one is based on equal costs of land parcels with different productivity, where the sale price of agriculture production is considered to be the same and is based on worse land plot. The second one - when harvest is expressed in kind or in money. Received money effects can be estimated by attaching to the world prices. The amount of differential rent Ia can be estimated in kind or in value units. The dif- ferences of harvest or its value are estimated between the values received from the subject land parcel in comparing with the worst one. Differential rent Ia can be estimated by using rates (tariffs) for an agricultural production unit. If the selling prices of production are the same for all producers, the differences in tariffs show the differences in generated income. The analysis of differential rent Ia shows, it can be received from the land parcels of better quality, while the worst ones cannot bring differential rent.

Differential rent Ib is called a location rent. It is received from the parcels that are closer to sale markets, if compared to the most remote ones that are used as farming lands. The transport costs are lower for the land parcels that are closer to agricultural production sales markets. It receives some extra profit that is a differential rent $\mathrm{Ib}$. Assessing the previously mentioned statements on differential rent Ia and Ib and the possibilities for its estimation, the following formula is proposed to be used for its additive calculation:

$$
R^{I a+I b}=\sum_{i j}\left(W_{i}-W_{j}\right) P_{i}\left(S_{j} / S_{I V}\right) C,
$$

where $i-i$ farming value of soil,

$j-j$ economic (tax) district,

$W_{i}$ - productivity of 4 grain types in $i$ economic value of soil (cnt/ha),

$W_{j}$ - productivity of 4 types of grain in a soil of bad quality (cnt/ha),

$P_{i}$ - area of $i$ soil economic value,

$S$ - area adjustment coefficients in $j$ and IV economic zone, $C$ - average market or buying-in price of 4 types of grain (Lt/cnt).

Natural productivity is understood as the potential productivity in the soils of different economic value by using ordinary technology. Natural productivity of every economic value soil should be compared with the productivity of the worst farming lands, which are regarded as 1 economic value. It means, there is no need to apply differential rent Ia for the worst soils.

Coefficients $S$ and $S_{v}$ for recalculation of area can be used in future for estimating agricultural taxes and evaluating farming lands of a land parcel depending on the location for realising agricultural products.

\subsection{Differential rent II}

Land rent decided by different technical conditions of land use is defined as differential rent II. First of all, technical use conditions are those called the built-up land, as houses and other structures, drainage, machinery, working tools, fertilisation by using organic and mineral materials, means for prevention of plants etc. The alternative for differentiated rent II is the amount of labour power within the land taxes. 
Different level of taxes for different land parcels (different productivity) is characterised by different amount of production and profit. Estimating the differential rent II, we take in advance a fixed tax level in the worst land plots, then estimate and identify tax increase for better land parcels. In such a way harvest, extras and profit is calculated. If such an increase in different land plots is higher than fixed tax level for the worst land plots, the difference received is a differential rent II. In principle, it is a matter of modelling because the differential rent I and the differential rent II is difficult to identify in practice. It is important to know the origin of the differential rent II and by analysing to find out whether it is worth to increase the intensity of agricultural production because extra inputs in land are not in direct proportion to a generated profit.

This problem can be analysed from a different aspect there is no need to cultivate all poor land in order to get some production. Such a land can be excluded from farming lands. Before starting farming activities it is necessary to evaluate the costs for improving land.

The intensification of plant growing results in direct increase of harvest from an area unit. Thanks to a higher production in better quality land the differential rent II is received. Its estimation can be expressed as:

$$
R^{I I}=\left(W_{r z}-W_{j}\right) C,
$$

where $W_{r z}$ is an average productivity of 4 types of grain (cnt/ha); $W_{i}$ - average productivity of 4 types of grain (cnt/ ha) calculated as balanced average harvest from different soil types; $C$-market price (sometimes minimal marginal buying-in price) for 4 grain types (Lt/cnt).

\subsection{Absolute rent}

Most theoretical problems arise because of an absolute rent seeking to include it in calculations and explaining its origin. Absolute rent is defined to be a value equal to the costs put in the worst land plots plus an average profit. In other words, the value created will be higher than the production price. At the same time it should be a payment quota for landowners for the worst land plots because even the plots of the lowest productivity require some investment. Theory of an absolute rent is based on the understanding that when an area of agricultural land is stable and private ownership monopoly exists, there is no land without an owner and the capital cannot freely flow to the agriculture. So, it should be worth paying the rent. As usual, the agricultural sector is worse technically equipped than other economy branches. That leads to an average profit. The live labour power of villagers is the only value measure in that process.

A better technical equipment of the agriculture production sector causes the reduction of absolute rent. Such practice exists in the developed countries. However, when a very small individual farm dominates in a country and there is a monopoly on processing and sale, such a small farm has no significant economic power and cannot maintain relatively high agricultural production prices. The supply of agricultural products is increasing in developed countries. Their prices have a tendency to decrease and the income gained by the producers of agricultural products is significantly lower than that for others working in other economy branches.

Absolute rent is an equivalent of public costs that appear when excluding the worst lands (Ist group) from farming lands. Public costs are equal to 90 tons of rye per 1 ha in 100 years. Summarising all above-mentioned statements, the absolute rent is expressed as follows:

$$
R=\left(W_{S} \times C\right) T \times P,
$$

where $W_{s}$ is an amount of public costs to remove the bad quality land (Ist group) from farming lands for non-agricultural purpose ( $1 \mathrm{cnt}$ of rye from 1 ha of such soil); $C$ is a market price of rye $(\mathrm{Lt} / \mathrm{cnt}) ; P$ - land area that is removed from farming lands; $T$ - a period for removing from farming lands (expressed in years).

However, the practice of many countries in the world shows that the agricultural land even of the worst quality is taxed. In such a situation the solvency of individual producers of agricultural products is lower than in other economic branches. It is possible to state that taxes received from the absolute rent of agricultural land in the budget must be equalised to the profit generated from forestry land.

\subsection{Land rent and land price}

In a market situation land becomes a commodity and must have its price. However, the costs for land price cannot be the prerequisite for treating it as a commodity because the land is not produced in a process of production.

The estimation of agricultural land price is a very important economic and societal problem. There is no land price yet. To estimate the value of land or its rent there is a need for an experience in manufacturing.

The value of agricultural land can be assessed by 3 methods as comparison, income or generalised and its price can be estimated using 3 different ways - comparison, profit (use) and residual value. Using the profit (use) method, two interpretations are possible - income capitalisation or discounting cash flows.

Land value is a capitalised land rent and calculated as the following:

$$
C_{Z}=(R \times 100) / P,
$$

where $C_{z}$ is land use value in LTL; $R$ is the land rent in LTL; $P$ is bank interest rate of cash deposits or granted credits. 


\section{The analysis of agricultural land market in the district of Kaunas}

The agricultural land market [15-19] in the district of Kaunas has been given a detailed investigation performed in the following order.

1. The entire district of Kaunas, taking into consideration its configuration and distances from city centre of Kaunas, has been divided on an M 1:50 000 into 7 circles [20-21]. The circles have been drawn in the following distances from city centre of Kaunas: the 1st circle - up to $10 \mathrm{~km}$; the 2 nd circle $-10-15 \mathrm{~km}$; the $3 \mathrm{rd}$ circle $-15-20 \mathrm{~km}$; the 4th circle $-20-25 \mathrm{~km}$; the 5 th circle $-25-30 \mathrm{~km}$; the 6th circle $-30-35 \mathrm{~km}$; the 7 th circle $->35 \mathrm{~km}$. Having taken into consideration supply data and geometrical configuration of the district, it was decided that supply data of the 5 th, 6 th and 7 th circles will be investigated homogeneously.

2. Further on, cadastral localities have been grouped according to circles. It has been noticed in the course of investigation that the formation of cadastral localities according to circles was unrealistic because of geometrical lay-out of localities unfavourable for investigations. Therefore a more detailed grouping of villages and settlements according to circles has been accepted.

3. An analysis of the investigated supply data has been carried out for each circle.

4. A correlation matrix has been formed and correlation coefficients of market data between separate circles have been calculated.

5. A probability model based on A. Foster's probability function has been adapted for processing market data.

6. Agricultural land market prices calculated with $95 \%$ probability and depending on the distance from city centre of Kaunas have been received.

7. Using the methods approved on the 24th of February, 1999 by Resolution No 205 of the Government, the fluctuation of nominal land prices has been calculated for every village grouping circle.

8. Using the methods for assessing the economic effi-

Table 1. Linear regression equations

\begin{tabular}{|c|l|}
\hline Circles & Regression equations \\
\hline $1-2$ & $y=1,16 x+594,2$ \\
\hline $1-3$ & $y=1,70 x-261,8$ \\
\hline $1-4$ & $y=2,02 x-197,6$ \\
\hline $1-5$ & $y=2,64 x-1751,8$ \\
\hline $2-3$ & $y=1,25 x-342,8$ \\
\hline $2-4$ & $y=1,35 x-83,1$ \\
\hline $2-5$ & $y=1,92 x-1380,6$ \\
\hline $3-4$ & $y=0,88 x+597,1$ \\
\hline $3-5$ & $y=1,31 x-415,7$ \\
\hline $4-5$ & $y=1,23 x-639,9$ \\
\hline
\end{tabular}

ciency of land, a calculation of price of a land lot situated in the second circle has been performed. A calculation of this price for the same farmer has been also performed according to Resolution No 205 of the Government of the Republic of Lithuania [22].

\subsection{Correlation matrix of market data between separate circles}

The number of acquired land market data sets for every circle distributed in the following way: 49, 42, 39, 22 and 34 . Therefore, when calculating correlation coefficients, the sets of data, depending on the length of the shortest row, were equalised.

The received matrix of correlation coefficients:

$$
r_{x y}=\left\|\begin{array}{ccccc}
1 & 0,93 & 0,95 & 0,87 & 0,97 \\
0,93 & 1 & 0,89 & 0,67 & 0,91 \\
0,95 & 0,89 & 1 & 0,86 & 0,98 \\
0,87 & 0,67 & 0,86 & 1 & 0,88 \\
0,97 & 0,91 & 0,98 & 0,88 & 1
\end{array}\right\| .
$$

Also, errors both of correlation coefficients and coefficients of regression equations have been taken into account. Regression equations have been worked out between separate circles of agricultural land market prices. The equations are in the Table 1.

Knowing market prices in one circle, it is possible by means of regression equations to forecast them in another circle. But there is no probabilistic valuation - the forecast of market prices is a non-probabilistic one. Thus in the next section, a probability model will be presented. Having adapted it for processing land market data, we can receive probabilistic market prices.

\subsection{Approximation of agricultural land market prices by means of A. Foster's probability curve}

For practical use, agricultural land market data of separate belts or circles around a social-economic attraction centre are approximated by means of A. Foster's probability curve (III type of Pearson's family of curves) [23]. In differential form, the equation of this curve can be expressed as:

$$
\frac{d p}{d x}=\frac{\gamma^{(m+1)}}{\Gamma(m+1)} \cdot e^{-\gamma(x-\bar{x}+l)} \cdot(x-\bar{x}+l)^{m},
$$

where $x$ - quantity under investigation,

$\bar{x}-$ its arithmetic average,

$\gamma=\frac{2}{\sigma \cdot C_{S}} ; m=\frac{4}{C_{S}^{2}-1} ; l=\frac{2 \sigma}{C_{S}}-$ parameters,

$e-$ base of natural logarithms,

$\Gamma(m+1)$ - gamma function. 
The value of probability $p$ is calculated according to the function:

$$
x_{p}=\bar{x}\left(F_{p} C_{v}+1\right)
$$

where: $x_{p}$ - variable quantity in the presence of probability $p$,

$\bar{x}-$ its arithmetic average,

$F_{p}-$ A. Foster's function,

$C_{v}-$ coefficient of variation,

$C_{S}-$ coefficient of asymmetry.

\section{Conclusions}

1. In case of insufficient amount of market data on land of agricultural purpose, it is problematic to determine its real market price.

2. When accumulating information on land sold on the market, it is necessary to determine the main factors having influence on the land market. It is needed to investigate further the reasons capable to accelerate the process of land market development: to investigate land offer and land demand, areas with demand to acquire land for private ownership etc.

3. Research on agricultural-purpose land market should be carried out based on evaluation methods substantiated by economical and scientific investigation, according to the prepared in advance schedules taking into account specific features of the site and other main factors having influence on land market.

4. The methodics for land pricing approved by the Decision No 205 of the Government of the Republic of Lithuania, dated Febr 24, 1999, contradicts the principles of market economy.

5. Work on land taken for public needs is impeded by the property right restoration for users having plots of land on road routes and by the double registration of land plots in the Register of Real Estate.

6. The principle defined by the decision No 1379 of the Government of the Republic of Lithuania, dated Oct 24, 1995, and stating the owner is to be compensated with real (market) price in cash for land taken for public needs, is in compliance with the main principle of many states on compensation for property taken for public needs.

\section{References}

1. ASABERE, P. K.; HUFFMAN, F. E. Thoroughfares and Apartment Values. Journal of Real Estate Research, 1996, 12(1), p. 9-16.

2. SO, H. M.; TSE, R. Y. C.; GANESAN, S. Estimating the influence of transport on house prices: evidence from Hong Kong. Journal of Property Valuation and Investment, 1997, 15 (1), p. 40-47.
3. WATKINS, C. Are new entrants to the residential property market informationally disadvantaged? Journal of Property Research, 1998, 15(1), p. 57-70.

4. DE CESARE, C. M.; RUDDOCK, L. A New Approach to the Analysis of Assessment Equity. Assessment Journal, 1998, 5(2), p. 57-69.

5. BRANAS-GARZA, P.; RODERO COSANO, J.; PRES LEY, J. R. The North-South divide and house price islands: the case of Córdoba (Spain). European Journal of Housing Policy, 2002, 2(1), p. 45-63.

6. BJÖRKLUND, K.; KLINGBORG, K. Correlation between Negotiated Rents and Neighbourhood Quality: A Case Study of Two Cities in Sweden. Housing Studies, 2005, 20(4), p. 627-648.

7. ROSEN, S. Hedonic prices and implicit markets: product differentiation in pure competition. Journal of Political Economy, 1974, 82, p. 34-55.

8. SÖDERBERG, B.; JANSSEN, C. Estimating Distance Gradients for Apartment Properties. Urban Studies, 2001, 38(1), p. 61-79.

9. GLOUDEMANS, R. J. Comparison of Three Residential Regression Models: Additive, Multiplicative, and Nonlinear. Assessment Journal, 2002, 9(4), p. 25-36.

10. O'CONNOR, P. M. Comparison of Three Residential Regression Models: Additive, Multiplicative, and Nonlinear. Assessment Journal, 2002, 9(4), p. 37-43.

11. HALVORSEN, R.; POLLAKOWSKI, H. O. Choice of functional form for hedonic price equations. Journal of Urban Economics, 1981, 10(1), p. 37-49.

12. WILHELMSSON, M. Spatial Models in Real Estate Economics. Housing, Theory and Society, 2002, 19, p. 92-101.

13. KAKLAUSKAS, A.; ZAVADSKAS, E. K.; BANAITIS, A.; ŠATKAUSKAS G. A method of defining the utility and market value of a real estate. International Journal of Strategic Property Management, 2007, 11(2), p. 107-120.

14. HARMAN, H. Modern factor analysis. 2nd ed, revised. The University of Chicago Press, 1998, p. 154-163.

15. International Valuation Standards 2005. 7th ed, International Valuation Standards Committee, London, 2005, p. 121.

16. European Valuation Standards 2003. 5th ed, TEGoVA and Estates Gazette, Bell \& Bain Ltd, Glasgow, 2003, p. 402.

17. RICS Appraisal and Valuation Standards. 5th ed. RICS Business Services Limited, 2003.

18. Appraisal institute. The Appraisal of Real Estate. 11 ed. Chicago, 1996, p. 820

19. LING, D.C.; ARCHER, W.R. Real estate principles: a value approach. McGraw-Hill, Boston, 2005. 706 p.

20. ŠATKAUSKAS, G. Approximation of separate land market data bases by means of A. Forster's probability curve. Real Estate Valuation and Investment, 1997, 2(2), p. 36-40.

21. ŠATKAUSKAS, G. Approximation of separate land market data bases by means of A. Foster's probability curve. Iš 9-oji tarpt. konferencija „Naujos statybinès medžiagos, konstrukcijos ir technologijos", 2007 m. gegužès 16-18 d. Vilnius: Technika, 2007, p. 177-178.

22. The Republic of Lithuania government's decree "About land valuation order", 1999, Febr. 24, No 205. News, 1999, No 21-597 (in Lithuanian).

23. OWEN, D. B. Handbook of statistical tables. Massachusetts: Edison-Wesley publishing company, INC, 1998, p. 273-285. 


\section{ŽEMĖS RINKOS EKONOMINIO IR MATEMATINIO MODELIO KONCEPCIJA}

\section{G. Šatkauskas}

\section{Santrauka}

İejimo parametrai, t. y. faktoriai, lemiantys žemès ukio paskirties žemès rinkos kainą, dažniausiai tarpusavyje susiję netiesiniais ryšiais. Šių ryšių stiprumas yra gana įvairus, o tai riboja informacijos naudingumą žemès rinkos kainu tyrimo procese. İejimo parametrų pokyčių efekto įtaka išẻjimo parametrams tais atvejais, kada pastebimi dideli pokyčiai, kažkuria viena kryptimi gali buti nustatomi gana tiksliai, o kitose kryptyse, kur įejimo parametrai mažai pakito, šiuos efektus sunku atskirti nuo „triukšmo“ fono.

Iš tiesų iẻjimo parametrų tarpusavio ryšiai sudaro nemažai skaičiavimo sunkumų: tai yra tiesinè priklausomybè tarp įejjimo parametrų ir tai rinkos duomenų kiekis mažesnis už nagrinejamų faktorių kieki (o tai charakteringa šiems rinkos tyrimams), kai kurių autorių siūlomos metodikos visai netaikytinos. Jeigu iẻjimo parametrai tarp savęs susiję gana stipriai, tada normalinių lygčiu sistemos koeficientu matricos apibrěžtumas žemas, o tai sukelia regresijos lygties koeficientų klaidų. Šios klaidos didèja didèjant įèjimo parametrų skaičiui.

Ivertinus išvardytas aplinkybes, žemės rinkos ekonominio ir matematinio modelio koncepcija turètų būti tokia: atliekama proceso reparametrizacija, ivvedant naujus parametrus tokiu būdu, kad nauji parametrai būtų tarpusavyje nekoreliuoti ir, esant minimaliam jų kiekiui, būtų ịvertinamas visas procesas. Šias sąlygas tenkina pagrindinès įėjimo parametrų komponentès. Paskui atliekama pagrindinių komponenčių normalizacija ir randamos priklausomybės pagal naujus parametrus. Kadangi gauti nauji iejjimo parametrai yra tarpusavyje nekoreliuoti, todèl supaprastėja regresijos lygčių statistinė analizè, sprendžiant normalines lygtis visuomet gaunami sprendiniai, o sumažinus įejjimo parametrų, paprasčiau interpretuoti gautas priklausomybes. Be to, kuo labiau pirminiųžemės rinkos duomenų tarpusavio priklausomybès skiriasi nuo tiesinių, tuo didesnis iėjimo parametrų komponenčių normalizavimo efektas.

Reikšminiai žodžiai: žemės rinka, rinka ir nominalus žemės vertinimas, masinio žemės vertinimo skaičiavimo metodai, nominali žemès kaina, žemės mokesčiai, nuoma.

Gintautas ŠATKAUSKAS. Assoc Prof at the Dept of Construction Economics and Property Management in Vilnius Gediminas Technical University. Research interests: real property valuation. 